\title{
The Effectiveness Differences of Adlerian Group Play Counseling and Classroom Guidance Activity in Improving Interpersonal Attractiveness
}

\section{Fajar Bilqis, Agus Taufiq, Ipah Saripah}

\author{
AUTHOR CORESPONDENCES: \\ Fajar Bilqis \\ Universitas Pendidikan Indonesia \\ Jalan Setiabudi Nomor 229, Bandung, \\ Jawa Barat 40154, Indonesia \\ Email: fajarbilqis@gmail.com

\section{Agus Taufiq} \\ Universitas Pendidikan Indonesia \\ Jalan Setiabudi Nomor 229, Bandung, \\ Jawa Barat 40154, Indonesia \\ Email:agustaufiq@upi.edu \\ Ipah SaripahUniversitas Pendidikan \\ Indonesia \\ Jalan Setiabudi Nomor 229, Bandung, \\ Jawa Barat 40154, Indonesia
} Email: ipahsaripah@upi.edu

\section{Halaman}

$92-97$

\begin{abstract}
This study was aimed at generating the empirical data on the effectiveness difference between Adlerian Group Play Counseling (AGPC) intervention and classical guidance service in improving interpersonal attractiveness based on the social relationship profile. This study was categorized as an experimental study with factorial design. The sample of this study comprised the fifth-grade students of Sukasenang Elementary School and Cihaurgeulis Elementary School. Interpersonal attractiveness questionnaire and sociometry emerged as the instruments of this study. The data were analyzed by using two-way analysis of variance. The result of this study demonstrated that AGPC intervention was more effective than the classroom guidance activity in improving all interpersonal attractiveness categories. The school counselor may utilize the result of this study as an alternative strategy to improve students' interpersonal attractiveness.

Keywords:Adlerian group play counseling, interpersonal attractiveness, classroom guidance activity
\end{abstract}

\begin{abstract}
ABSTRAK
Studi bertujuan untuk menghasilkan data empirik mengenai perbedaan keefektifan antara intervensi Adlerian Group Play Counseling (AGPC) dan layanan bimbingan klasikal dalam meningkatkan daya tarik interpersonal berdasarkan profil hubungan sosial. Studi menggunakan desain penelitian factorial design experimental. Sampel penelitian adalah seluruh siswa kelas V Sekolah Dasar Sukasenang dan Sekolah Dasar Cihaurgeulis. Instrumen penelitian yang digunakan adalah angket daya tarik interpersonal dan sosiometri. Teknik analisis data menggunakan analisis variansi dua arah. Hasil penelitian menunjukkan intervensi Adlerian Group Play Counseling lebih efektif meningkatkan daya tarik interpersonal dibandingkan layanan bimbingan klasikal. Hasil studi dapat digunakan oleh konselor sekolah untuk membantu siswa meningkatkan daya tarik interpersonal.
\end{abstract}


Kata kunci: adlerian group play counseling, daya tarik interpersonal, bimbingan klasikal

\section{INTRODUCTION}

Children' social development is one of the aspects that need teachers and parents' attention. The children social developmental task during the period I (9-14 years old) is to learn to socialize and to work in a peer group (Hurlock, 2004; Sumantri \& Syaodih, 2006). Social development is essential for the children' whole development. It affects the learning activeness (Santrock, 2007), children self-adjustment (Hurlock, 2004), and trust on the others (Sujiono, 2013). Moreover, it triggers social characters (Yusuf, 2009), establishes self-reflection (Sunarto \& Hartono, 2006), selfconcept (Santrock, 2007), responsible personality, autonomy, satisfied social needs, and ease of success achievement (Carnegie, 2006).

The excellent social development of children is directly in line with their friendship relation. Every good friendship relation contains a good interpersonal attractiveness. Interpersonal attractiveness itself plays a pivotal role in the children' social development (Dewi, 2013). Faturrahman (2006) and Montoya and Horton (2014) stated that attractiveness is one of the bases of social relationship.

In this study, the result of the preliminary study which was attained by using sociometry, interviews, and observations towards some teachers and students of the Sukasenang Elementary School and Cihargeulis Elementary School indicated that some students did not possess interpersonal attractiveness. Without other people' assistance, children cannot develop and interact with their surroundings. It demands the elementary school counselor to provide a service that attempts to assist the students in improving their interpersonal attractiveness.

Adlerian Group Play Counseling (AGPC) is one of the approaches of the guidance and counseling which is considered as a perfect approach for improving children' interpersonal attractiveness. Through this approach, they can develop their social interest and socialize with their peers. In line with this statement, Danger (2003) points out that the group play therapy has been related to the improvement of social acceptance. A child, who is assumed to have a good social acceptance, possesses proximity and familiarity with his/her surrounding that affects on the interpersonal attractiveness (Berscheid \& Walster, 1978).

Unlike the AGPC, classroom guidance activity is an easier service with a shorter period and may guide many students at once in a meeting. The success of this activity does not only rely on the counselor but also on the students' condition (Rismawati, 2015) Therefore, if the atmosphere during the activity is less conducive, the result will not be optimum (Prahardika, 2014).

This study aims to find out the effectiveness differences between AGPC and classroom guidance activity to improve the elementary school students' interpersonal attractiveness. The interpersonal attractiveness is one of the aspects that support the quality of the interpersonal relationship. The elementary school counselor may take the result of this study as the strategy to improve the students' interpersonal attractiveness.

\section{METHODOLOGY}

This study was classified as an experimental study by utilizing a factorial design. The subject of this study consisted of seventy-two students of grade X at SMA Negeri 4 Bandung. The sample was taken by using a purposive sampling technique. This study employed the interpersonal attractiveness questionnaire, sociometry, observation guide, and interview guide to collect the data. In addition, this study used two-way ANOVA to analyze the data.

\section{RESULTS AND DISCUSSION}

Grounded on the data analysis, the post-intervention data demonstrated that there was a different level of interpersonal attractiveness. However, that interpersonal attractiveness was not affected by the social relationship. In other words, there was no interaction between the types of the intervention and the social relationship. Compared to the classroom guidance activity, AGPC intervention was more effective in improving all categories of interpersonal attractiveness namely popular sociometry group, neglected, controversial, and rejected. Table 1 provided the statistic description, and Table 2 denoted the result of Two-Way ANOVA analysis. 
Table 1

Descriptive Statistics of Interpersonal Attractiveness

\begin{tabular}{|c|c|c|c|c|}
\hline $\begin{array}{l}\text { Sociome } \\
\text { try }\end{array}$ & $\begin{array}{l}\text { Types of } \\
\text { Counseling }\end{array}$ & Mean & $\begin{array}{c}\text { Std. } \\
\text { Deviation }\end{array}$ & $\mathrm{N}$ \\
\hline \multirow[t]{5}{*}{ Popular } & AGPC & 93.3333 & 8.94161 & 15 \\
\hline & Classroom & 58.4286 & 9.29611 & 14 \\
\hline & Guidance & & & \\
\hline & Activity & & & \\
\hline & Total & 76.4828 & 19.87932 & 29 \\
\hline \multirow{5}{*}{$\begin{array}{l}\text { Neglect } \\
\text { ed }\end{array}$} & AGPC & 91.2500 & 9.69168 & 8 \\
\hline & Classroom & 63.0000 & 8.79935 & 8 \\
\hline & Guidance & & & \\
\hline & Activity & & & \\
\hline & Total & 77.1250 & 17.11091 & 16 \\
\hline \multirow{5}{*}{$\begin{array}{l}\text { Controv } \\
\text { ersial }\end{array}$} & AGPC & 91.4444 & 12.74864 & 9 \\
\hline & Classroom & 69.6667 & 8.10864 & 9 \\
\hline & Guidance & & & \\
\hline & Activity & & & \\
\hline & Total & 80.5556 & 15.26327 & 18 \\
\hline \multirow[t]{5}{*}{ Rejected } & AGPC & 93.0000 & 17.57840 & 3 \\
\hline & Classroom & 60.3333 & 17.78576 & 3 \\
\hline & Guidance & & & \\
\hline & Activity & & & \\
\hline & Total & 76.6667 & 23.88026 & 6 \\
\hline \multirow[t]{5}{*}{ Total } & AGPC & 92.3429 & 10.47109 & 35 \\
\hline & Classroom & 62.6471 & 10.34813 & 34 \\
\hline & Guidance & & & \\
\hline & Activity & & & \\
\hline & Total & 77.7101 & 18.17812 & 69 \\
\hline
\end{tabular}

AGPC may assist the students in improving the interpersonal attractiveness through a dialog and game. According to Bevins (in Danger, 2003), the game process demands the children learn to accept and to be accepted by other people. Accordingly, the popular and the controversial children will understand more about the isolated children, and vice versa. This process leads the popular and controversial children to select the neglected and rejected children.The neglected and rejected ones including the popular and controversial children will choose each other. It is in line with a statement stating that AGPC generates mutual relationships between two or more counselees and the counselors (Landreth, 2012; Sweeney, Baggerly, \& Ray, 2014).

In general, AGPC in this study aims to compensate a deficient interpersonal attractiveness to construct a positive-managed interpersonal attractiveness. Specifically, AGPC attempts to grow trust, awareness, identity, sense of universality, self-esteem, social skill, honesty, value modification, conflict resolution, wise choice-making, responsibility, and to change a specific behavior (Kottman, 2001; Corey in Sweeney, Baggerly, \& Ray, 2014).

Table 2

Tests of Between-Subjects Effects: Interpersonal Attractiveness Level

\begin{tabular}{|c|c|c|c|c|c|c|}
\hline Source & $\begin{array}{l}\text { Type III Sum } \\
\text { of Squares }\end{array}$ & $d f$ & Mean Square & $\mathrm{F}$ & Sig. & $\begin{array}{l}\text { Partial Eta } \\
\text { Squared }\end{array}$ \\
\hline $\begin{array}{l}\text { Corrected } \\
\text { Model }\end{array}$ & $15951.052^{a}$ & 7 & 2278.722 & 21,322 & .000 & .710 \\
\hline Intercept & 301465.048 & 1 & 301465.048 & $\begin{array}{l}2820.82 \\
3\end{array}$ & .000 & .979 \\
\hline Sociometry & 250,278 & 3 & 83,426 & .781 & .509 & .037 \\
\hline $\begin{array}{l}\text { Counseling } \\
\text { Types }\end{array}$ & 10829.871 & 1 & 10829.871 & 101,336 & .000 & .624 \\
\hline $\begin{array}{l}\text { Sociometry* } \\
\text { Counseling } \\
\text { Types }\end{array}$ & 500,177 & 3 & 166,726 & 1,560 & .208 & .071 \\
\hline Error & 6519.151 & 61 & 106,871 & & & \\
\hline Total & 439152.000 & 69 & & & & \\
\hline $\begin{array}{l}\text { Corrected } \\
\text { Total }\end{array}$ & 22470.203 & 68 & & & & \\
\hline a. R Squared & 710 (Adjuste & So & $\mathrm{ed}=.677)$ & & & \\
\hline
\end{tabular}


The stages of AGPC were as follow: establishing a relationship, exploring children' problem, assisting children to understand their lifestyle, clarifying the values that will be internalized, and patenting the internalized values (Corey, Corey, \& Corey, 2008). The result of the study on the AGPC conducted by Meany-Walen \& Teeling (2016) indicated that AGPC is effective if it is given to three participants in which each participant shows his/her will. Besides, the study carried out by Akay \& Bratton (2017) found that AGPC effectively reduces the children maladaptive perfectionism and the related anxiety problems. In addition, Taylor \& Brattor (2014) noted that AGPC is the most implemented counseling model in the game-based approach. Hence, in this study, AGPC is proven effective in improving the elementary school students' interpersonal attractiveness,

This study also implements the intervention with classroom guidance activity. Classroom guidance activity is one of the guidance curricula that targets all the students in a class or the combination of some classes in the form of class discussion or brainstorming and delivers the information that leads to the maximum development of the learners' autonomy (ABKIN, 2007; Supriyo, 2010).

The classroom guidance activity demands the counselor to contact with the students in the class directly. Moreover, the classroom guidance activity is scheduled and is in the form of class discussion and brainstorming (Putro, 2015).According to Monica \& Susanti (2017), classroom guidance activity is undergone through the prepared material such as Guidance and Counseling service plan.

The classroom guidance activity attempts to inform or orientate the students in developing their potential and reaching their developmental tasks to obtain the goal of education (Makrifah \& Nuryono, 2014). The function of the classroom guidance activity is to identify the students who need specific service, preventive service, and to create educative interaction between the counselor and the counselee (Farozin, 2012). The classroom guidance activity consists of six steps divided into three stages namely pre-activity, main activity, and post-activity. The steps carried out during the pre-activity stage is initial (the need understanding and the classroom method picking) and preparing (material, systematics, and media). During the main activity, the steps comprise opening, working, and termination. In the post-activity, the evaluation is undergone (Webb \& Brigman, 2006).

The classroom guidance activity is not a process of teaching or delivering material. Instead, it delivers the information that may affect all aspects of the students' autonomy or development. Consequently, there is a relationship between the guidance activity and the teaching activity in the class. Grounded on the study result, the classroom guidance activity can improve the elementary school students' interpersonal attractiveness. AGPC, however, brings more significant improvement. It is supported by the result of the study conducted by Mukhtar, Yusuf, \& Budiamin (2016) which showed that the classroom guidance activity is effective to improve the students' self-control. Furthermore, Susanto (2015) in his study indicates that the classroom guidance activity is effective to form the attitudes toward pre-marriage sex at SMA Pangudi Luhur Santo Yosef Surakarta.

Interpersonal attractiveness is related to the similar attitude, background, values, and beliefs. An individual tends to possess more positive emotion towards the other individuals with the same attitude (Batool \& Malik, 2010). There are two factors of interpersonal attractiveness, personal and situational factor. The personal factor includes the response of being liked, fear reduction, and similarity. The situational factor, conversely, entails proximity, teamwork, intimacy, physical attractiveness, and skill (Berscheid \& Walster, 1978).

Interpersonal attractiveness is based on the evaluation of the individual' quality evidenced by some signs such as similar attitude, positive quality, and physical attractiveness (Horton \& Montoya, 2004). Someone who possesses interpersonal attractiveness exhibits more positive behavior (Langlois et al., 2000) and owns more significant social influence (Singh \& Tor, 2008). Social influence is indicated by better treatment, more appreciation for their performance and more acceptance, satisfied social needs, receiving better results, positive self-concept, more motivated, more productive, and more sustainable physically or psychologically (Utami, 2015; Nurfitri, 2008; Faturrahman, 2006). Without attractiveness, a person will be isolated. 
The characteristics of the children who possess interpersonal attractiveness were personal warmth and competency. Finkel, et al. (2015) stated that proximity affects interpersonal attractiveness. The interpersonal attractiveness of the social group member is one of the most fundamental and consequential psychological phenomena. The study carried out by Krause et al. (2014) about the interpersonal attractiveness within a small group has exclusively discussed the explicit evaluation of the other social partners. In line with the dual-process approach, it denotes that the implicit aspects of interpersonal attractiveness differ from the explicit aspects, and this automatic evaluation possesses direct social consequence that exceeds the effect of explicit desire.

Interpersonal attractiveness relates to the social behavior. Based on the study conducted by Sari and Siswati (2016), there is a significant positive relationship between the interpersonal attractiveness and the pro-social behavior. It demonstrates that higher interpersonal attractiveness leads to the higher pro-social behavior of the adolescents and vice versa. The interpersonal attractiveness effectively accounts for $38.8 \%$ on the pro-social behavior.

\section{CONCLUSION}

This study concludes that the AGPC intervention is more effective than the classroom guidance activity in improving all categories of interpersonal attractiveness. The elementary school counselor may take the results of this study as the strategy to improve the students' interpersonal attractiveness.

\section{REFERENCES:}

ABKIN. (2007). Penataan Pendidikan Profesional Konselor dan Layanan Bimbingan dan Konseling dalam Jalur Pendidikan Formal. Jakarta: Departemen Pendidikan Nasional.

Akay, S., \& Bratton, S. (2017). The Effects of Adlerian Play Therapy on Maladaptive Perfectionism and Anxiety in Children: A Single Case Design. International Journal of Play Therapy, 26(2), 96.

Batool, S., \& Malik, N. I. (2010). Role of Attitude Similarity and Proximity in Interpersonal Attraction among Friends (C310). International Journal of Innovation, Management and Technology,1(2), 142.
Berscheid, E. \& Walster, E. (1978). Interpersonal Attraction 2nd Edition. Boston: Addison Wesley Publishing Company.

Corey, S.M., Corey, G., \& Corey, C. (2008). Group: Process and Practice. California: Brooks/Cole.

Danger, S.E. (2003). Child-centered Group Play Therapy with Children with Speech Difficulties. (Dissertation). University of North Texas, Texas.

Dewi, A.D.A.K. (2013). Studi Komparasi FaktorFaktor Daya Tarik Interpersonal Pada Mahasiswa UNNES yang Berpacaran Ditinjau Dari Jenis Kelamin. Journal of Social and Industrial Psychology, 2 (1), 32-44.

Farozin, M. (2012). Pengembangan Model Bimbingan Klasikal untuk Meningkatan Motivasi Belajar Siswa SMP. Cakrawala Pendidikan, 31(1), 143-156.

Faturrahman. (2006). Psikologi Sosial. Yogyakarta: Pustaka.

Finkel, E. J., Norton, M. I., Reis, H. T., Ariely, D., Caprariello, P. A., Eastwick, P. W.,\& Maniaci, M. R. (2015). When does Familiarity Promote Versus Undermine Interpersonal Attraction? A Proposed Integrative Model from Erstwhile adversaries. Perspectives on Psychological Science, 10(1), 3-19.

Horton, R.S. \& Montoya, R.M. (2004). Interpersonal Relation and Group Processes on the Importance of Cognitive Evaluation as a Determinant of Interpersonal Attraction.Journal of Personality and Social Psychology,86(5), 696-712.

Hurlock, E. (2004). Psikologi Perkembangan. Jakarta: PT Gramedia Pustaka.

Kottman, T. (2001). Adlerian play therapy. International Journal of Play Therapy, 10 (2), 1-12.

Krause, S., Back, M. D., Egloff, B., \& Schmukle, S. C. (2014). Implicit Interpersonal Attraction in Small Groups: Automatically Activated Evaluations Predict Actual Behavior toward Social Partners. Social Psychological and Personality Science, 5(6), 671-679.

Landreth, G.L. (2012). Play therapy: The Art of the Relationship, Third Edition. New York: Taylor \& Francis Group, LLC.

Langlois, J. H. dkk. (2000). Maxims or Myths of Beauty? A Meta-analytic and Theoretical review. Psychological Bulletin, 126(3), 390-423.

Makrifah, F.L. \& Nuryono, W. (2014). Developing 
Specialization Package in Classical Counseling Services for Junior High School Students. Jurnal BK Unesa, 04 (03), 1-8.

Meany-Walen, K. K., \& Teeling, S. (2016). Adlerian play therapy with students with Externalizing Behaviors and Poor Social Skills. International Journal of Play Therapy, 25(2), 64.

Monica, M. A., \& Susanti, D. (2017). Efektivitas Bimbingan Klasikal Menggunakan Media AudioVisual untuk Mengembangkan Interaksi Sosial Peserta Didik Kelas VIII Semester Ganjil di SMPN 26 Bandar Lampung Tahun Pelajaran 2016/2017. Konseli: Jurnal Bimbingan dan Konseling, 3(2), 331. 346.

Montoya, R.M. \& Horton, R.S. (2014). A Two-dimensional Model for the Study of Interpersonal Attraction. Pers Soc Psychol Rev, 18(1), 59-86.

Mukhtar, M., Yusuf, S., \&Budiamin, A. (2016). Program Layanan Bimbingan Klasikal untuk Meningkatkan Self-Control Siswa. PSIKOPEDAGOGIA Jurnal Bimbingan dan Konseling, 5(1), 1-16.

Prahardika, A. N. (2014). Upaya Meningkatkan Pemahaman Bahaya Bullying Melalui Bimbingan Klasikal pada Siswa. PSIKOPEDAGOGIA Jurnal Bimbingan dan Konseling. 3(1), 50-56.

Putro, E. A. (2015). Upaya Meningkatkan Adversity Quotient Melalui Pelaksanaan Bimbingan Klasikal (Penelitian pada Mahasiswa Semester III Program Studi Bimbingan dan Konseling FKIP UNISRI Tahun 2014/2015). Jurnal Widya Wacana, 10(1), 21-29.

Rismawati, R. (2015). Pelaksanaan Layanan Klasikal Bimbingan dan Konseling di SMP Negeri 3 Kandangan. Jurnal Mahasiswa Bk An-Nur, 1(1), 64-73.

Santrock, J.W. (2007). Psikologi Perkembangan. Edisi 11 Jilid 1. Jakarta: Erlangga.

Sari, I. K., \&Siswati. (2016). Hubungan Antara Ketertarikan Interpersonal dengan Perilaku Prososial pada Remaja SMA Islam Hidayatullah Semarang. Jurnal Empati, 5(4), 711-716.

Singh, R. \& Tor, X.L. (2008). The Relative Effects of Competence and Likability on Interpersonal Attraction. The Journal of Social Psychology, 148(2), 253255.

Sujiono, Y.N. (2013). Konsep Dasar Pendidikan Anak Usia Dini. Jakarta: PT Indeks.
Sumantri, M \& Syaodih, N. (2006). Perkembangan Peserta Didik. Jakarta: Universitas Terbuka.

Sunarto, A. \& Hartono, A. (2006). Perkembangan Peserta Didik, Jakarta: PT Asdi Mahasatya.

Supriyo. (2010). Teknik Bimbingan Klasikal. Semarang: Swadaya Publishing.

Susanto, J. R. (2015). Efektivitas Program Pelayanan Bimbingan Klasikal Mengenai Seksualitas dalam Membentuk Sikap terhadap Hubungan Seks Pranikah di SMA Pangudi Luhur Santo Yosef Surakarta. Disertasi tidak Diterbitkan. Salatiga: Program Studi Psikologi Universitas Kristen Satya Wacana.

Sweeney, D.S., Baggerly, J.N., \& Ray, D.C. (2014). Group Play Therapy: A dynamic Aproach. New York: EvS Communication Networx, Inc.

Taylor, D. D., \& Bratton, S. C. (2014). Developmentally Appropriate Practice: Adlerian Play Therapy with Preschool Children. The Journal of Individual Psychology, 70(3),205-219.

Utami, P. W. (2015). Faktor-faktor yang Memengaruhi Komunikasi Interpersonal Guru dan Siswa Kelas IIIB SDIT Luqman Alhakim Internasional, Banguntapan, Bantul. Jurnal Pendidikan Guru Sekolah Dasar, 4 (4), 1-12.

Webb, L.D. \& Brigman, G.A. (2006). "Student Success Skills: Tools and Strategies for Improved Academic and Social Outcomes Professional School Counseling. Proquest Education Journals, 10 (2), 112. Yusuf, S. (2009). Psikologi Perkembangan Anak Dan Remaja. Bandung: PT Remaja Rosdakarya Suryabrata. 